\title{
Top End Pulmonary Hypertension Study: Understanding Epidemiology, Therapeutic Gaps and Prognosis in Remote Australian Setting
}

\section{Abstract}

Introduction: The Top End of Australia has a high proportion of Indigenous people with a high burden of chronic cardiac and pulmonary diseases likely to contribute to pulmonary hypertension $(\mathrm{PH})$. The epidemiology of $\mathrm{PH}$ has not been previously studied in this region.

Methods: Patients with $\mathrm{PH}$ were identified from the Northern Territory echocardiography database from January 2010 to December 2015 and followed to the end of 2019 or death. PH was defined as a tricuspid regurgitation velocity $\geq 2.75 \mathrm{~m} / \mathrm{s}$ measured by Doppler echocardiography. The etiology of $\mathrm{PH}$, as categorized by published guidelines, was determined by reviewing electronic health records.

Results: 1764 patients were identified comprising 49\% males and 45\% Indigenous people. The prevalence of $\mathrm{PH}$ was 955 per 100,000 population (with corresponding prevalence of 1587 for Indigenous people). Hypertension, atrial fibrillation, diabetes and respiratory disease were present in $85 \%, 45 \%, 41 \%$ and $39 \%$, respectively. Left heart disease was the leading cause for $\mathrm{PH}(58 \%)$, the majority suffering from valvular disease (predominantly rheumatic). Pulmonary arterial hypertension $(\mathrm{PAH})$, respiratory disease related $\mathrm{PH}$, chronic thromboembolic $\mathrm{PH}$ (CTEPH) and unclear multifactorial $\mathrm{PH}$ represented $4 \%, 16 \%, 2 \%$ and $3 \%$, respectively. Underlying causes were not identifiable in $17 \%$ of the patients. Only $31 \%$ of potentially eligible patients were on $\mathrm{PAH}$-specific therapy. At census, there was $40 \%$ mortality, with major predictors being age, ePASP and Indigenous ethnicity.

Conclusion: $\mathrm{PH}$ is prevalent in Northern Australia, with a high frequency of modifiable risk factors and other treatable conditions. Whether earlier diagnosis, interpretation and intervention improves outcomes merits further assessment.

Keywords: Pulmonary Hypertension, Indigenous, Remote Australia, 
medRxiv preprint doi: https://doi.org/10.1101/2020.09.19.20197988; this version posted September 22, 2020. The copyright holder for this preprint (which was not certified by peer review) is the author/funder, who has granted medRxiv a license to display the preprint in perpetuity.

It is made available under a CC-BY 4.0 International license.

\section{Introduction}

Pulmonary hypertension $(\mathrm{PH})$ is a debilitating medical condition with a poor prognosis. It is not a single disease process, but rather a haemodynamic sequalae of several underlying pathologies. There are five distinct $\mathrm{PH}$ classification groups [1], and the management and prognosis of each is very different $[2,3]$. $\mathrm{PH}$ is traditionally defined as mean pulmonary artery pressure $(\mathrm{mPAP}) \geq 25 \mathrm{mmHg}$, measured at rest via right heart catheterization $(\mathrm{RHC})$ [2]. This definition of $\mathrm{PH}$ has been changed recently with the pressure reduced to $\geq 20 \mathrm{mmHg}$ [1], due to data suggesting mildly elevated pulmonary artery pressures may be associated with increased mortality $[4,5]$. In clinical practice, echocardiography provides the first objective evidence of $\mathrm{PH}$ and other valuable information such as presence or absence of left heart pathology. It may also provide evidence of increased pulmonary vascular resistance (PVR), a necessary parameter to diagnose pulmonary arterial hypertension $(\mathrm{PAH})$, the only group of $\mathrm{PH}$ with evidence based specific PH therapy [6]. Despite the development of multiple advanced $\mathrm{PH}$ therapies over the last two decades [7], the mean survival of $\mathrm{PH}$ patients is approximately four years from the first recorded elevated pulmonary pressure by echocardiography [8, 9]. Emerging data suggest that the prevalence of all types of $\mathrm{PH}$ is rising $[8,10]$. There was a recent report from Central Australia investigating its epidemiology [11]. We sought to evaluate $\mathrm{PH}$ in the Top End of Australia where nearly two-thirds of the Northern Territory (NT) population live and have access to diagnostics and therapy through a tertiary hospital.

\section{Background and Study Rationale}

The medical service delivery is challenging in the Top End of Australia due to tyranny of distance for many residents, limited health resources and health inequity faced by the Aboriginal and Torres Straits Islanders who represent approximately $27 \%$ of the population [12]. Non-communicable chronic diseases (e.g. coronary artery disease, hypertension, diabetes) as well as communicable chronic diseases (e.g. rheumatic heart disease) are highly prevalent in 
the region [13]. These may lead to $\mathrm{PH}$ and subsequent burden of morbidity and mortality in the absence of or delay in management of underlying pathology. Advanced $\mathrm{PH}$ therapy is recommended for the treatment of $\mathrm{PAH}$, however it requires specialist centre prescription, careful monitoring and is expensive [14]. Moreover, there are significant delays in definitive diagnosis of $\mathrm{PH}$ leading to delayed commencement of appropriate therapy $[15,16]$. Better understanding of $\mathrm{PH}$ epidemiology will allow better planning and management of scarce health resources and thence hopefully improve the outcomes. We have a unique advantage of studying epidemiology of PH in the Top End as a single cardiology service, NT Cardiac Pty Ltd, provides the echocardiography service to the whole region. This improves data capture and integrity not only from the point of view of individual cases but also the availability of all cardiac investigations for review.

We hypothesized that the prevalence of $\mathrm{PH}$ in the Top End is higher than elsewhere in Australia and potentially contributes to the life expectancy gap between Indigenous and non-Indigenous Australians. Hence, we conducted this cohort study to better document the epidemiology, associated comorbidities and prognosis of $\mathrm{PH}$ in this region.

\section{Methods}

\subsection{Ethics, study design and data sources}

Ethics clearance was obtained from the Human Research Ethics Committee of the NT Department of Health and Menzies School of Health Research. Structured Query Language (SQL) queries were made in the NT Cardiac echo-database to identify echocardiograms with maximal tricuspid regurgitation velocity $\left(T R V_{\text {max }}\right) \geq 2.75 \mathrm{~m} / \mathrm{s}$, which is equivalent to estimated pulmonary artery systolic pressure (ePASP) $\geq 40 \mathrm{mmHg}$ assuming a right atrial pressure of $10 \mathrm{mmHg}$, a methodology consistent with previous studies $[8,17]$. Only residents of the Top End were included. Data were collected from echocardiograms performed between January 2010 and December 2015 and the patients were followed up until death or the end of 2019, 
medRxiv preprint doi: https://doi.org/10.1101/2020.09.19.20197988; this version posted September 22, 2020. The copyright holder for this preprint (which was not certified by peer review) is the author/funder, who has granted medRxiv a license to display the preprint in perpetuity.

It is made available under a CC-BY 4.0 International license .

whichever occurred first. When multiple echocardiograms were found for the same patient, the first echocardiogram was used to determine the classification and severity of $\mathrm{PH}$. Corresponding clinical information were collected from electronic medical records (EMRs) from both the Department of Health and NT Cardiac. The date of diagnosis was defined as the first date an echocardiogram showed evidence of PH which could be the date before January 2010. Survival and follow-up time were calculated as the time difference between the date of diagnosis and death or census date. Patient's place of residence was determined by the current post code. The Strengthening the Reporting of Observational Studies in Epidemiology (STROBE) guidelines in reporting were strictly followed [18].

\subsection{Study Setting}

Top End is the upper half of the NT and contains four main regions: Darwin, Kakadu national park, Arnhem land and Katherine region. It covers an area of approximately $245,000 \mathrm{~km}^{2}$ and had a population of 184,657 according to 2016 census data. The cardiology service is provided by NT Cardiac based in Darwin with regular outreach specialists' visits to remote communities and to the two regional hospitals (Katherine and Gove District Hospital).

\subsection{Determining the PH classification}

A diagnostic algorithm slightly modified from the current guidelines was used in classifying patients into $\mathrm{PH}$ groups as illustrated in figure 1 [2]. The indexed echocardiogram report was first reviewed to look for left heart pathologies defined as moderate to severe left sided valvular (aortic and mitral) disease and left ventricular (LV) systolic or diastolic dysfunction (figure 1). These were determined by the reporting cardiologist in accordance with the American Society of Echocardiography (ASE) guidelines [19-21]. The presence of congenital heart disease was also identified in the echocardiogram report. Presence of significant (moderate to severe) respiratory pathologies (sleep apnoea, obstructive and restrictive lung disease) were 
medRxiv preprint doi: https://doi.org/10.1101/2020.09.19.20197988; this version posted September 22, 2020. The copyright holder for this preprint (which was not certified by peer review) is the author/funder, who has granted medRxiv a license to display the preprint in perpetuity.

It is made available under a CC-BY 4.0 International license .

determined by extensive review of the EMRs. Further causes of $\mathrm{PH}$ such as portal hypertension, chronic kidney disease and connective tissue diseases were also identified in the EMRs. If more than one cause of $\mathrm{PH}$ was present for one patient, the most severe pathology was recorded as the etiology of $\mathrm{PH}$. Patients were classified as $\mathrm{PAH}$ only if $\mathrm{RHC}$ was performed and pre-capillary $\mathrm{PH}$ physiology (Pulmonary artery wedge pressure $(P A W P) \leq 15 \mathrm{mmHg}$ and $\mathrm{PVR}>3 \mathrm{WU}$ ) were demonstrated, and no alternative causes were identified. A few exceptions to this rule were patients who had evidence of portal hypertension who could be classified as portopulmonary hypertension (PPHTN), and patients with congenital heart diseases known to cause PAH. Patients without any identifiable pathology were labelled as $\mathrm{PH}$ with unidentifiable cause, only after exhaustive review of all available records.

\subsection{Statistical Methods}

Statistical analysis was performed using International Business Machines Statistical Package for the Social Sciences (IBM® SPSS) 26.0 software. The continuous variables were reported as mean ( \pm standard deviation) or median (interquartile range/IQR) as appropriate. Pearson's chisquare test was used to compare the categorical variables while Student's t-test was used to compare the means. Man-Whitney $U$ test was used to compare the medians. The Kaplan-Meier method was used for survival analysis. Cox regression analysis was performed to determine factors associated with increased mortality.

\section{Results}

\subsection{Study Cohort and overall prevalence of pulmonary hypertension}

There were total of 46,731 echocardiograms performed during the study period. Initially 2072 echocardiograms were identified after removing duplicates with the same hospital record numbers and those performed in Central Australia (Figure 2). After resolution of duplicates and 
medRxiv preprint doi: https://doi.org/10.1101/2020.09.19.20197988; this version posted September 22, 2020. The copyright holder for this preprint (which was not certified by peer review) is the author/funder, who has granted medRxiv a license to display the preprint in perpetuity.

It is made available under a CC-BY 4.0 International license .

exclusion of patients who were not residents of Top End and two patients with missing clinical data, the final cohort for analysis consisted of 1764 patients. Thus, the prevalence of $\mathrm{PH}$ in the Top End was 955 per 100,000. The prevalence for the Indigenous population was 1587 per 100,000 population (791 $\mathrm{PH}$ patients for 49,857 Indigenous inhabitants calculated as $27 \%$ of 184,657 from 2016 census).

\subsection{Clinical characteristics and comorbidities}

The study cohort was evenly distributed between biological sex (49\% male). Indigenous patients represented $45 \%(\mathrm{~N}=791)$ of the study population while making up $27 \%$ of the total population. The mean age of the entire cohort was $60 \pm 18$ years. Indigenous patients were younger at diagnosis with a mean age of $48 \pm 18$ years compared to $69 \pm 14$ years for nonIndigenous patients $(P=<0.001)$. This trend was true across all clinical classification groups as shown in Figure 3. The cohort contained 62\% mild (PASP $40-49 \mathrm{mmHg}$ ), $22 \%$ moderate (PASP 50-59 $\mathrm{mmHg}$ ) and 16\% severe $\mathrm{PH}(\mathrm{PASP} \geq 60 \mathrm{mmHg}$ ) patients. The chronic diseases and modifiable risk factors were highly prevalent as illustrated in Table 1. Among the risk factors, smoking, diabetes, chronic kidney disease and left heart disease were more prevalent in Indigenous patients while atrial fibrillation and obstructive sleep apnoea were more common in non-Indigenous patients. There were 33 patients younger than 18 years of age in the cohort. The majority $(n=26)$ was due to left heart disease and rheumatic heart disease was the underlying cause in 21 out of 26 patients. Six young patients had congenital heart disease. The cause was not identifiable in one child with $\mathrm{PH}$.

\subsection{Differences among the $\mathrm{PH}$ groups}

The comparison of demographics among the different $\mathrm{PH}$ groups is illustrated in Table 2. PAH was responsible for $4 \%$ of the cohort. $\mathrm{PH}$ due to left heart disease (PH-LHD) was the predominant group, making up $58 \%$ of the total cohort. Respiratory disease related $\mathrm{PH}$ was 
accounted for $16 \%$ of the patients while chronic thromboembolic $\mathrm{PH}(\mathrm{CTEPH})$ and unclear, multifactorial $\mathrm{PH}$ were responsible for $2 \%$ and $3 \%$ of the patients, respectively. The etiology of $\mathrm{PH}$ was not identifiable in $17 \%$ of the patients despite thorough search of the available medical records.

Valvular heart disease was responsible for $55 \%$ of patients with PH-LHD while left ventricular systolic dysfunction and diastolic dysfunction were responsible for $29 \%$ and $16 \%$ of $\mathrm{PH}$-LHD patients, respectively. Left atrial size was reported to be dilated in 849 out of $982 \mathrm{PH}$-LHD patients (86\%) where left atrial size was documented. Among $\mathrm{PH}$ patients with unidentifiable cause, $48 \%$ were reported to have dilated left atria. PAH patients were generally younger at diagnosis with a mean age of $41 \pm 19$ years.

\subsection{PAH patients and advanced $\mathrm{PH}$ therapy}

There were four iPAH patients among the PAH group. Congenital heart disease was the most common cause of PAH in the cohort with $43 \%$, followed by connective tissue disease related $\mathrm{PAH}$ (PAH-CTD) with 29\%. Systemic lupus erythematosus (SLE) related $\mathrm{PH}$ was almost exclusive to Indigenous women (13 out of 16 patients) while no Indigenous patient was diagnosed with systemic sclerosis. All four iPAH patients received dual therapy with an endothelin receptor antagonist (ERA) and a phosphodiesterase 5 (PDE5) inhibitor. PPHTN due to cirrhosis of liver was the underlying etiology for 15 patients (22\% of $\mathrm{PAH}$ patients). Only one PPHTN patient received advanced PAH-specific therapy. Overall, only 21 out of 68 patients (31\%) with $\mathrm{PAH}$ received one form of advanced therapy.

\subsection{Mortality data and predictors of increased risk}

At the end of 2019, with a median (IQR) follow-up of 5.1 (2.9-7.4) years, there were $40 \%$ of patients with confirmed mortality (Figure 4). PH-RD was associated with the highest mortality, 
closely followed by PH caused by unclear, multifactorial causes. PH-LHD patients also suffered a high mortality with approximately $30 \%$ mortality at 5 years from diagnosis. $\mathrm{PAH}$ patients experienced the best prognosis in our cohort despite the low percentage of them receiving advanced therapy. Cox regression survival model analysis revealed that age at diagnosis $(0.03 \%$ increase in risk for every year increase in age $)$ and ePASP $(0.012 \%$ increase in risk for every $1 \mathrm{mmHg}$ increase) were significant predictors of mortality. There was no gender-based difference in mortality. Indigenous status was associated with increased mortality (HR=1.796 (1.496-2.155), $\mathrm{P}=0.001$ ) (Table 3 and Figure 5).

\section{Discussion}

This is the most comprehensive description of $\mathrm{PH}$ in the Top End of Australia to date. Our study provides rich and comprehensive information regarding the prevalence and the root causes of $\mathrm{PH}$ in our region and complements the findings of the previously published Central Australian Study to complete the picture for the whole NT. PH was common, with a prevalence of approximately $1 \%$ of the total population in the Top End and was associated with a high mortality. The Indigenous population not only had a higher prevalence (1.6\%), but also a higher mortality risk associated with $\mathrm{PH}$. They were also diagnosed with $\mathrm{PH}$ at younger age.

The major strengths of our study were the integrity of the dataset due to the coverage of the area by a single echocardiographic database and all echocardiograms performed by certified, experienced cardiac sonographers and reported by experienced cardiologists. A limitation of our study was that we described the minimum predicted prevalence as the data was retrospectively obtained from an echocardiography database rather than prospectively screening the whole population. We may have also missed $\mathrm{PH}$ patients with insufficient tricuspid regurgitation to estimate PASP due to our study design, a finding highlighted by other studies of this type [8]. The RHCs were performed only in 92 patients $(5.2 \%$ of the study cohort). This limitation may be the reason that the underlying cause was not found in a large 
portion (17\%) of our cohort. Without confirmation of elevated PVR by RHC, the diagnosis of precapillary $\mathrm{PH}$ or PAH cannot be made and patients would not be able to access effective advanced $\mathrm{PH}$ therapies $[1,2]$. Nonetheless, elevated pulmonary pressure estimated from $\mathrm{TRV}_{\max }$ in echocardiography show an important signal towards a higher prevalence of $\mathrm{PH}$. On the other hand, using $\mathrm{TRV}_{\max }$ alone without other echocardiographic signs suggestive of $\mathrm{PH}$ in patients with intermediate probability of $\mathrm{PH}$ (TRVmax 2.9 to $3.4 \mathrm{~m} / \mathrm{s}$ ) may overestimate the prevalence in our study [2]. Many diagnoses and classification for the studied patients were "presumptive" and based on retrospective data. However, they highlight the important nature of this set of diseases and the need for comprehensive evaluation of every patient with pulmonary hypertension suspected on echocardiography.

There were different risk factor profiles between the Indigenous and non-Indigenous patients and specific tailored interventions may be considered to reduce these risk factors in both populations. The burden of risk factors and comorbidities were high in this region where approximately $30 \%$ of population was Indigenous and had high prevalence of rheumatic heart disease. We found that left heart disease was the leading cause of $\mathrm{PH}$ in our study in agreement with previous reports [8, 22]. Most patients in this group had valvular heart disease which likely depicts the ongoing public health problem of high prevalence of rheumatic heart disease in our region. Although PAH-CTD patients represented only small proportion of the cohort, there were specific demographic groups within this cohort, e.g., SLE-PAH being almost an exclusive disease of Indigenous women and no systemic sclerosis being diagnosed in Indigenous population. The remote, rural, Indigenous population also continue to suffer from preventable childhood $\mathrm{PH}$ caused by rheumatic heart disease in high numbers.

The prevalence of all types of $\mathrm{PH}$ in Top End was approximately three times higher than observed in the Armadale echo study [8] and higher than reported from Central Australia [11]. Epidemiology of $\mathrm{PH}$ worldwide is highly heterogenous creating challenges to clinicians and health authorities trying to tackle this emerging health problem. A function of reducing the pressure criteria for the haemodynamic definition of $\mathrm{PH}$ will result in a significant a priori 
increase in the prevalence of $\mathrm{PH}[1]$. The hope is that this may lead to better outcomes through earlier commencement of disease-modifying treatment [23]. The findings from our study may help promote the awareness of $\mathrm{PH}$ as a sequalae of treatable conditions in the unique and vulnerable population of the Top End.

The burden of heart failure with preserved ejection fraction (HFpEF) is increasing [24] and it is estimated that 50 to $>80 \%$ of HFpEF patients have $\mathrm{PH}$ [22]. Hypertension, the major cause of left ventricular diastolic dysfunction and HFpEF, was found to be very common in our study. We suspect that the prevalence of PH-LHD was underestimated due to our strict criteria in defining $\mathrm{PH}-\mathrm{LHD}$. Left atrial dilatation, an indicator of left heart pathology, was present in $48 \%$ of $\mathrm{PH}$ patients without an identifiable cause, reinforcing our suspicion.

The population studied exemplifies many of the difficulties of managing a rural, remote population in an era of increasing medical specialization. Many patients had multiple comorbidities and chronic diseases with multiorgan involvement requiring multiple specialists' input. This could potentially lead to disjointed care resulting in suboptimal outcomes. A specialist multidisciplinary $\mathrm{PH}$ clinic with a collaborative approach would be an ideal care model and establishment of these in resource poor setting could be challenging but worth consideration. The fact that $17 \%$ of the cohort did not have an attributable cause for $\mathrm{PH}$ was an indication for under-recognition and under-investigation of $\mathrm{PH}$ in the region.

\subsection{Future directions}

Based on findings of this study, it is proposed that region-specific diagnostic algorithms and referral pathways based on current clinical guidelines could assist with early diagnosis of $\mathrm{PH}$. We intend to link our data with the National Echo Database Australia (NEDA)[25, 26] which will enable us to investigate the echocardiographic screening tools in triaging patients who require further invasive investigations [6, 27]. This is highly relevant in the Top End where there are many remote patients who will benefit from such readily available, non-invasive screening 
methods. A population screening approach may be beneficial and should be considered in regions our study identified to have disproportionately high prevalence of $\mathrm{PH}$. Potential establishment of electronic database for ongoing prospective evaluation and monitoring therapy for these high-risk patients need to be considered. The delay in diagnosis could be mitigated by development and implementation of region-specific diagnostic algorithms. Prognosis could be improved by establishment of multidisciplinary model of care for early comprehensive assessment and intervention of underlying conditions (such as timely heart valve surgery) and commencement of evidence-based therapy for PAH patients.

\section{Conclusion}

Pulmonary hypertension in the Top End of Australia was considerably more common compared to previously published community cohort studies. Indigenous patients developed $\mathrm{PH}$ at younger age but suffered higher mortality. Modifiable risk factors for $\mathrm{PH}$ were also prevalent prompting an urgent need to adopt a preventive strategy. Underutilization of advanced therapy in PAH patients as well as apparent under-investigation need further investigation and mitigation to improve outcomes. 


\section{References}

1. Simonneau G, Montani D, Celermajer DS, Denton CP, Gatzoulis MA, Krowka M, et al. Haemodynamic definitions and updated clinical classification of pulmonary hypertension. Eur Respir J. 2018:1801913.

2. Galie N, Humbert M, Vachiery JL, Gibbs S, Lang I, Torbicki A, et al. 2015 ESC/ERS Guidelines for the diagnosis and treatment of pulmonary hypertension. Eur Heart J. 2016;37(1):67-119.

3. Hoeper MM, McLaughlin VV, Dalaan AM, Satoh T, Galie N. Treatment of pulmonary hypertension. Lancet Respir Med. 2016;4(4):323-36.

4. Strange G, Stewart S, Celermajer DS, Prior D, Scalia GM, Marwick TH, et al. Threshold of Pulmonary Hypertension Associated With Increased Mortality. J Am Coll Cardiol. 2019;73(21):2660-72.

5. Kovacs G, Berghold A, Scheidl S, Olschewski H. Pulmonary arterial pressure during rest and exercise in healthy subjects: a systematic review. Eur Respir J. 2009;34(4):888-94.

6. Naing P, Kuppusamy H, Scalia G, Hillis GS, Playford D. Non-Invasive Assessment of Pulmonary Vascular Resistance in Pulmonary Hypertension: Current Knowledge and Future Direction. Heart Lung Circ. 2017;26(4):323-30.

7. Galie N, Channick RN, Frantz RP, Grunig E, Jing ZC, Moiseeva O, et al. Risk stratification and medical therapy of pulmonary arterial hypertension. Eur Respir J. 2019;53(1).

8. Strange G, Playford D, Stewart S, Deague JA, Nelson H, Kent A, et al. Pulmonary hypertension: prevalence and mortality in the Armadale echocardiography cohort. Heart. 2012;98(24):1805-11.

9. Strange G, Lau EM, Giannoulatou E, Corrigan C, Kotlyar E, Kermeen F, et al. Survival of Idiopathic Pulmonary Arterial Hypertension Patients in the Modern Era in Australia and New Zealand. Heart Lung Circ. 2018;27(11):1368-75.

10. Wijeratne DT, Lajkosz K, Brogly SB, Lougheed MD, Jiang L, Housin A, et al. Increasing Incidence and Prevalence of World Health Organization Groups 1 to 4 Pulmonary Hypertension: A PopulationBased Cohort Study in Ontario, Canada. Circ Cardiovasc Qual Outcomes. 2018;11(2):e003973.

11. Haji K, Wong CX, Chandra N, Truong H, Corkill W, Kaethner A, et al. Pulmonary Hypertension in Central Australia: A Community-Based Cohort Study. Heart Lung Circ. 2019;28(4):598-604.

12. Zhao Y, Guthridge S, Falhammar H, Flavell H, Cadilhac DA. Cost-effectiveness of stroke care in Aboriginal and non-Aboriginal patients: an observational cohort study in the Northern Territory of Australia. BMJ Open. 2017;7(10):e015033.

13. Zhao Y, Jeyaraman K, Burgess P, Connors C, Guthridge S, Maple-Brown L, et al. All-cause mortality following low-dose aspirin treatment for patients with high cardiovascular risk in remote Australian Aboriginal communities: an observational study. BMJ Open. 2020;10(1):e030034.

14. Maron BA, Galie N. Diagnosis, Treatment, and Clinical Management of Pulmonary Arterial Hypertension in the Contemporary Era: A Review. JAMA Cardiol. 2016;1(9):1056-65.

15. Strange G, Gabbay E, Kermeen F, Williams $T$, Carrington $M$, Stewart $S$, et al. Time from symptoms to definitive diagnosis of idiopathic pulmonary arterial hypertension: The delay study. Pulm Circ. 2013;3(1):89-94.

16. Khou V, Anderson JJ, Strange G, Corrigan C, Collins N, Celermajer DS, et al. Diagnostic delay in pulmonary arterial hypertension: Insights from the Australian and New Zealand pulmonary hypertension registry. Respirology. 2020.

17. McQuillan Brendan M, Picard Michael H, Leavitt M, Weyman Arthur E. Clinical Correlates and Reference Intervals for Pulmonary Artery Systolic Pressure Among Echocardiographically Normal Subjects. Circulation. 2001;104(23):2797-802. 
18. von Elm E, Altman DG, Egger M, Pocock SJ, Gotzsche PC, Vandenbroucke JP. Strengthening the Reporting of Observational Studies in Epidemiology (STROBE) statement: guidelines for reporting observational studies. Bmj. 2007;335(7624):806-8.

19. Zoghbi WA, Adams D, Bonow RO, Enriquez-Sarano M, Foster E, Grayburn PA, et al. Recommendations for Noninvasive Evaluation of Native Valvular Regurgitation: A Report from the American Society of Echocardiography Developed in Collaboration with the Society for Cardiovascular Magnetic Resonance. J Am Soc Echocardiogr. 2017;30(4):303-71.

20. Nagueh SF, Smiseth OA, Appleton CP, Byrd BF, 3rd, Dokainish H, Edvardsen T, et al. Recommendations for the Evaluation of Left Ventricular Diastolic Function by Echocardiography: An Update from the American Society of Echocardiography and the European Association of Cardiovascular Imaging. J Am Soc Echocardiogr. 2016;29(4):277-314.

21. Baumgartner H, Hung J, Bermejo J, Chambers JB, Evangelista A, Griffin BP, et al. Echocardiographic Assessment of Valve Stenosis: EAE/ASE Recommendations for Clinical Practice. J Am Soc Echocardiogr. 2009;22(1):1-23.

22. Guazzi M, Galie N. Pulmonary hypertension in left heart disease. Eur Respir Rev. 2012;21(126):338-46.

23. Stewart $S$, Strange GA, Playford D. The challenge of an expanded therapeutic window in pulmonary hypertension. Nat Rev Cardiol. 2020;17(4):195-7.

24. Naing P, Forrester D, Kangaharan N, Muthumala A, Mon Myint S, Playford D. Heart failure with preserved ejection fraction: A growing global epidemic. Aust J Gen Pract. 2019;48(7):465-71.

25. Strange G, Celermajer DS, Marwick T, Prior D, Ilton M, Codde J, et al. The National Echocardiography Database Australia (NEDA): Rationale and methodology. Am Heart J. 2018;204:186-9.

26. Playford D, Strange G, Scalia G, Stewart S, Marwick T, Keogh A, et al. Making Australia the Benchmark in Echocardiography Databases: The National Echo Database Australia (NEDA). Heart Lung Circ. 2016;25:S241.

27. Scalia GM, Scalia IG, Kierle R, Beaumont R, Cross DB, Feenstra J, et al. ePLAR - The echocardiographic Pulmonary to Left Atrial Ratio - A novel non-invasive parameter to differentiate precapillary and post-capillary pulmonary hypertension. International journal of cardiology. 2016;212:37986. 


\section{Figures and Tables}

Table. 1. The frequency of risk factors and chronic diseases in the study cohort of patients living in the Top End of Australia with pulmonary hypertension

\begin{tabular}{|c|c|c|c|c|c|}
\hline Risk Factors & $\begin{array}{l}\text { All patients with } \\
\text { risk factors } \\
\mathrm{N} \text { (\% of patients } \\
\text { with known } \\
\text { comorbidity } \\
\text { status) }\end{array}$ & $\begin{array}{l}\text { Indigenous } \\
\text { patients with } \\
\text { risk factors } \\
\mathrm{N} \text { (\% of patients } \\
\text { with known } \\
\text { comorbidity } \\
\text { status) }\end{array}$ & $\begin{array}{l}\text { Non- } \\
\text { indigenous } \\
\text { patients with } \\
\text { risk factors } \\
\mathrm{N} \text { (\% of } \\
\text { patients with } \\
\text { known } \\
\text { comorbidity } \\
\text { status) }\end{array}$ & $\begin{array}{l}\text { Odds ratio } \\
\text { (95\% } \\
\text { Confidence } \\
\text { Interval)* }\end{array}$ & $\begin{array}{l}\text { P-value } \\
\text { between } \\
\text { Indigenous } \\
\text { and Non- } \\
\text { Indigenous } \\
\text { patients }\end{array}$ \\
\hline Obesity & $229(18 \%$ of 1287$)$ & $105(16 \%$ of 659$)$ & $\begin{array}{l}124(20 \% \text { of } \\
628)\end{array}$ & $\begin{array}{l}0.77(0.58- \\
1.03)\end{array}$ & 0.07 \\
\hline Smoking & $\begin{array}{l}1021(61 \% \text { of } \\
1684)\end{array}$ & $586(76 \%$ of 774$)$ & $\begin{array}{l}435(48 \% \text { of } \\
910)\end{array}$ & $\begin{array}{l}3.40(2.76- \\
4.20)\end{array}$ & $<0.001$ \\
\hline Diabetes & $718(41 \%$ of 1751$)$ & $419(53 \%$ of 791$)$ & $\begin{array}{l}299(31 \% \text { of } \\
961)\end{array}$ & $\begin{array}{l}2.50(2.06- \\
3.04)\end{array}$ & $<0.001$ \\
\hline Hypertension & $\begin{array}{l}1493(85 \% \text { of } \\
1755)\end{array}$ & $690(87 \%$ of 790$)$ & $\begin{array}{l}803(83 \% \text { of } \\
965)\end{array}$ & $\begin{array}{l}1.39(1.06- \\
1.82)\end{array}$ & 0.02 \\
\hline Atrial Fibrillation & $787(45 \%$ of 1749$)$ & $298(38 \%$ of 788$)$ & $489(51 \%$ of & $0.59(0.49-$ & $<0.001$ \\
\hline
\end{tabular}


medRxiv preprint doi: https://doi.org/10.1101/2020.09.19.20197988; this version posted September 22, 2020. The copyright holder for this preprint (which was not certified by peer review) is the author/funder, who has granted medRxiv a license to display the preprint in perpetuity.

It is made available under a CC-BY 4.0 International license .

\begin{tabular}{|c|c|c|c|c|c|}
\hline$(A F)$ & & & 961) & $0.71)$ & \\
\hline $\begin{array}{l}\text { Chronic Lung } \\
\text { Disease }\end{array}$ & $689(39 \%$ of 1764$)$ & $320(41 \%$ of 791$)$ & $\begin{array}{l}369(38 \% \text { of } \\
973)\end{array}$ & $\begin{array}{l}1.11(0.92- \\
1.35)\end{array}$ & 0.28 \\
\hline Cirrhosis of liver & $133(8 \%$ of 1753$)$ & $75(10 \%$ of 790$)$ & $58(6 \%$ of 963$)$ & $\begin{array}{l}1.64(1.15- \\
2.34)\end{array}$ & 0.006 \\
\hline $\begin{array}{l}\text { Chronic Kidney } \\
\text { Disease (CKD) }\end{array}$ & $659(38 \%$ of 1754$)$ & $414(53 \%$ of 789$)$ & $\begin{array}{l}245(25 \% \text { of } \\
965)\end{array}$ & $\begin{array}{l}3.24(2.65- \\
3.97)\end{array}$ & $<0.001$ \\
\hline $\begin{array}{l}\text { Obstructive } \\
\text { Sleep Apnoea } \\
\text { (OSA) }\end{array}$ & $196(11 \%$ of 1753$)$ & $56(7 \%$ of 789$)$ & $\begin{array}{l}140(15 \% \text { of } \\
964)\end{array}$ & $\begin{array}{l}0.45(0.33- \\
0.62)\end{array}$ & $<0.001$ \\
\hline $\begin{array}{l}\text { Connective } \\
\text { Tissue Disease }\end{array}$ & $58(3.4 \%$ of 1697$)$ & $28(3.6 \%$ of 768$)$ & $\begin{array}{l}30(3.2 \% \text { of } \\
929)\end{array}$ & $\begin{array}{l}1.13(0.67- \\
1.92)\end{array}$ & 0.64 \\
\hline $\begin{array}{l}\text { Left Heart } \\
\text { Disease }\end{array}$ & $\begin{array}{l}1042(59 \% \text { of } \\
1764)\end{array}$ & $528(67 \%$ of 791$)$ & $\begin{array}{l}514(53 \% \text { of } \\
973)\end{array}$ & $\begin{array}{l}1.79(1.48- \\
2.18)\end{array}$ & $<0.001$ \\
\hline
\end{tabular}

*of having risk factors between Indigenous and Non-indigenous patients 
Table 2. Demographics of patients in the study cohort, living in the Top End of Australia, according to the clinical classification of Pulmonary Hypertension

\begin{tabular}{|c|c|c|c|c|c|c|c|}
\hline & $\begin{array}{l}\text { All } \\
\text { patients }\end{array}$ & PAH & PH-LHD & PH-RD & CTEPH & $\begin{array}{l}\text { Miscellane } \\
\text { ous }\end{array}$ & $\begin{array}{l}\text { Unclassifia } \\
\text { ble }\end{array}$ \\
\hline Number & $\begin{array}{l}1764 \\
(100 \%)\end{array}$ & $\begin{array}{l}68 \\
(4 \%)\end{array}$ & $\begin{array}{l}1020 \\
(58 \%)\end{array}$ & $\begin{array}{l}275 \\
(16 \%)\end{array}$ & $38(2 \%)$ & $63(3 \%)$ & $300(17 \%)$ \\
\hline $\begin{array}{l}\text { Age at } \\
\text { diagnosis } \\
\text { (mean } \pm S D \\
\text { years) }\end{array}$ & $60 \pm 18$ & $41 \pm 19$ & $58 \pm 19$ & $65 \pm 14$ & $56 \pm 15$ & $63 \pm 16$ & $63 \pm 16$ \\
\hline $\begin{array}{l}\text { ePASP } \\
\text { (median } \\
(\mathrm{IQR}) \\
\mathrm{mmHg})\end{array}$ & $\begin{array}{l}47(43- \\
54)\end{array}$ & $\begin{array}{l}50 \\
(46- \\
71)\end{array}$ & $\begin{array}{l}47(43- \\
55)\end{array}$ & $\begin{array}{l}49(44- \\
57)\end{array}$ & $\begin{array}{l}51(46- \\
59)\end{array}$ & $51(43-56)$ & $45(42-50)$ \\
\hline Indigenous & $\begin{array}{l}791 \\
(45 \%)\end{array}$ & $\begin{array}{l}41 \\
(60 \%)\end{array}$ & $\begin{array}{l}519 \\
(51 \%)\end{array}$ & $\begin{array}{l}94 \\
(34 \%)\end{array}$ & $4(11 \%)$ & $44(70 \%)$ & $89(30 \%)$ \\
\hline Male & $\begin{array}{l}868 \\
(49 \%)\end{array}$ & $\begin{array}{l}23 \\
(34 \%)\end{array}$ & $\begin{array}{l}522 \\
(51 \%)\end{array}$ & $\begin{array}{l}149 \\
(54 \%)\end{array}$ & $\begin{array}{l}23 \\
(61 \%)\end{array}$ & 17 (27\%) & $134(45 \%)$ \\
\hline Mortality* & $\begin{array}{l}704 \\
(40 \%)\end{array}$ & $\begin{array}{l}19 \\
(28 \%)\end{array}$ & $\begin{array}{l}411 \\
(40 \%)\end{array}$ & $\begin{array}{l}145 \\
(53 \%)\end{array}$ & $\begin{array}{l}10 \\
(26 \%)\end{array}$ & $33(52 \%)$ & $86(29 \%)$ \\
\hline
\end{tabular}

$\mathrm{PAH}=$ Pulmonary Arterial Hypertension, $\mathrm{PH}-\mathrm{LHD}=$ Pulmonary Hypertension due to left heart disease, $\mathrm{PH}-\mathrm{RD}=$ Pulmonary Hypertension due to respiratory disease, $\mathrm{CTEPH}=$ Chronic Thromboembolic Pulmonary Hypertension, ePASP = estimated pulmonary artery systolic 
medRxiv preprint doi: https://doi.org/10.1101/2020.09.19.20197988; this version posted September 22, 2020. The copyright holder for this preprint (which was not certified by peer review) is the author/funder, who has granted medRxiv a license to display the preprint in perpetuity.

It is made available under a CC-BY 4.0 International license .

pressure, $\mathrm{SD}=$ standard deviation. ${ }^{*}=$ at the end of 2019, median (IQR) follow-up was 5.1 (2.9-

7.4) years.

Table 3. Different variables predicting increased mortality in patients with pulmonary hypertension living in the Top End of Australia

\begin{tabular}{|l|l|l|}
\hline & $\begin{array}{l}\text { Hazard Ratio }(95 \% \\
\text { Cl) }\end{array}$ & P-values \\
\hline Age at Diagnosis & $1.033(1.027-1.039)$ & 0.001 \\
\hline Male gender & $1.123(0.967-1.306)$ & 0.129 \\
\hline Indigenous status & $1.796(1.496-2.155)$ & 0.001 \\
\hline ePASP & $1.012(1.006-1.018)$ & 0.001 \\
\hline
\end{tabular}

$\mathrm{Cl}=$ confidence interval 
medRxiv preprint doi: https://doi.org/10.1101/2020.09.19.20197988; this version posted September 22, 2020. The copyright holder for this preprint (which was not certified by peer review) is the author/funder, who has granted medRxiv a license to display the preprint in perpetuity.

It is made available under a CC-BY 4.0 International license .

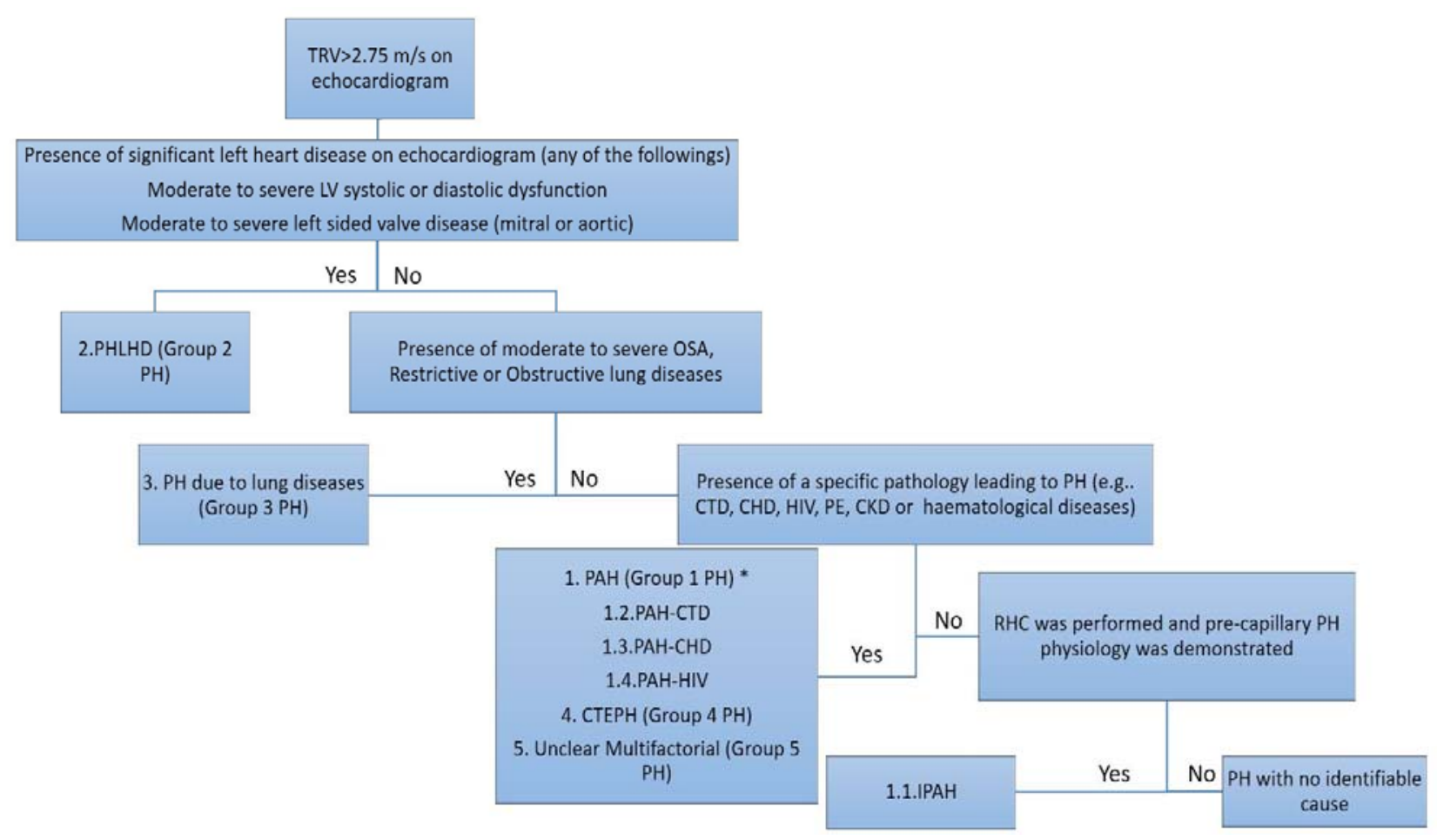

Figure 1. Diagnostic algorithm used in the study. TRV= tricuspid regurgitation velocity, $L V=$ left ventricle, $P H-L H D=$ pulmonary hypertension due to left heart disease, $P H=$ pulmonary hypertension, OSA= obstructive sleep apnoea, $P E=$ pulmonary embolism, HIV= human immunodeficiency virus infection, $C T D=$ connective tissue disease, $C K D=$ chronic kidney disease, $C H D=$ congenital heart disease, $P A H=$ pulmonary artery hypertension, CTEPH= chronic thromboembolic pulmonary hypertension, IPAH= idiopathic PAH, RHC= right heart catheterisation, *if $\mathrm{RHC}$ was performed and pre-capillary $\mathrm{PH}$ physiology was demonstrated except in patients with portal hypertension and $\mathrm{CHD}$ that can cause PAH 
medRxiv preprint doi: https://doi.org/10.1101/2020.09.19.20197988; this version posted September 22, 2020. The copyright holder for this preprint (which was not certified by peer review) is the author/funder, who has granted medRxiv a license to display the preprint in perpetuity.

It is made available under a CC-BY 4.0 International license .

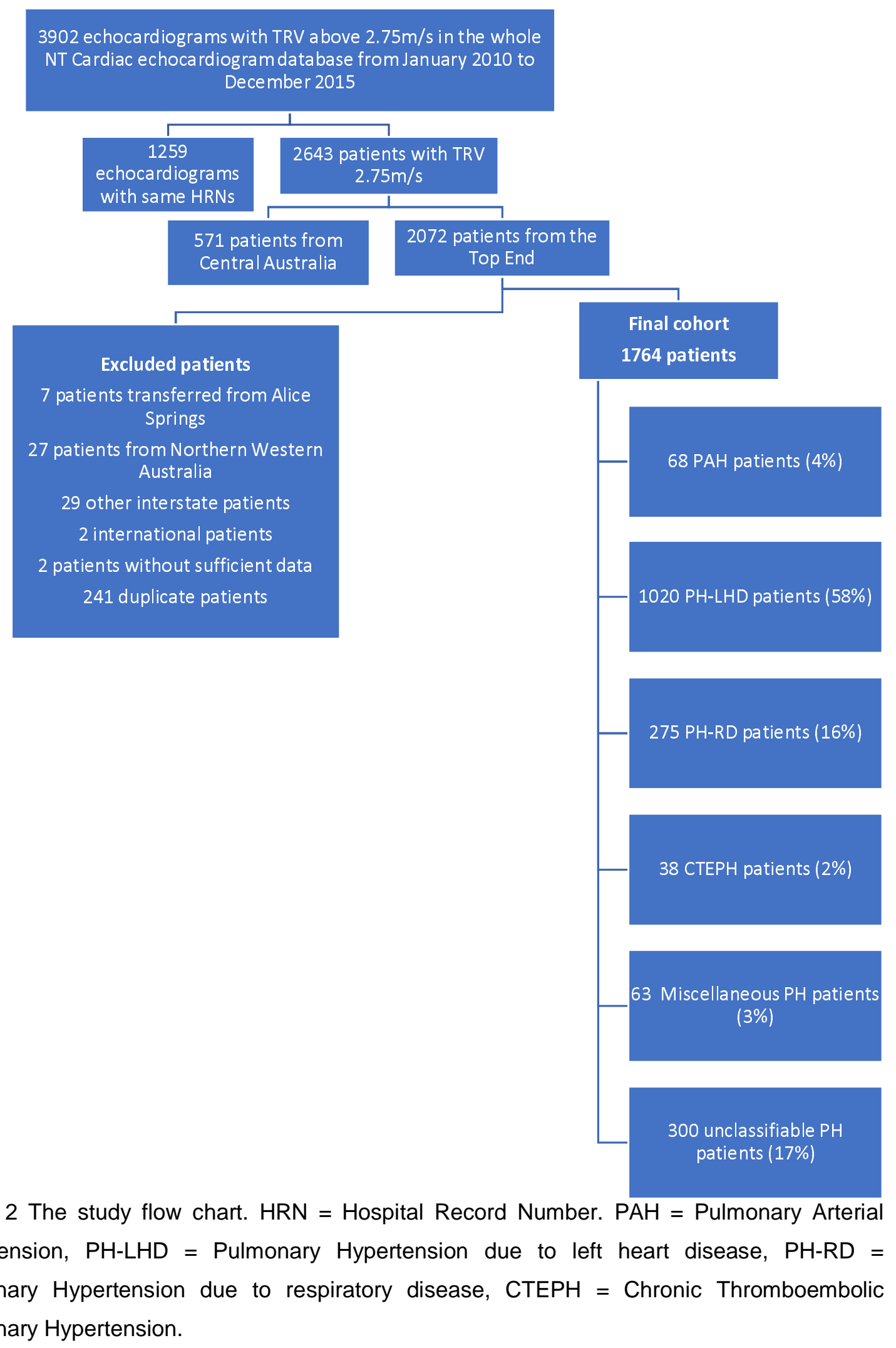

Figure 2 The study flow chart. HRN = Hospital Record Number. PAH = Pulmonary Arterial Hypertension, PH-LHD = Pulmonary Hypertension due to left heart disease, $\mathrm{PH}-\mathrm{RD}=$ Pulmonary Hypertension due to respiratory disease, $\mathrm{CTEPH}=$ Chronic Thromboembolic Pulmonary Hypertension. 


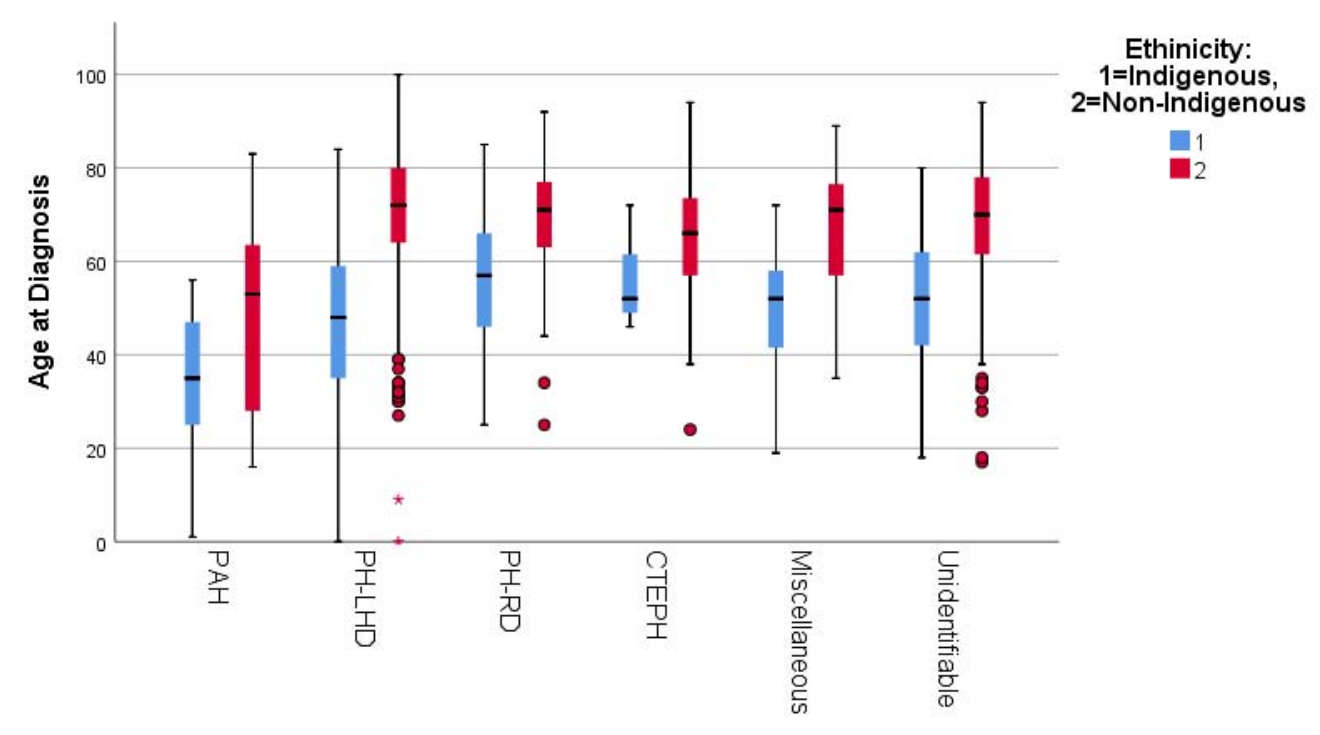

Clinical Classification

Figure 3. The box and whisker chart illustrating median age at diagnosis (the solid bar), interquartile range (the box) and highest and lowest values (the whiskers) and the outliers (the circles) according to different clinical classification of pulmonary hypertension $(\mathrm{PH})$. Indigenous patients were younger at diagnosis in all $\mathrm{PH}$ classification groups. $\mathrm{PAH}=$ Pulmonary Arterial Hypertension, $\mathrm{PH}-\mathrm{LHD}=$ Pulmonary Hypertension due to left heart disease, $\mathrm{PH}-\mathrm{RD}=\mathrm{Pulmonary}$ Hypertension due to respiratory disease, $\mathrm{CTEPH}=$ Chronic Thromboembolic Pulmonary Hypertension. P-value $=<0.001$ when comparing the median age at diagnosis for all Indigenous patients [49 (37-60)] years with Non-indigenous patients [71 (62-78 years)] using Mann-Whitney U test 
medRxiv preprint doi: https://doi.org/10.1101/2020.09.19.20197988; this version posted September 22, 2020. The copyright holder for this preprint (which was not certified by peer review) is the author/funder, who has granted medRxiv a license to display the preprint in perpetuity.

It is made available under a CC-BY 4.0 International license .

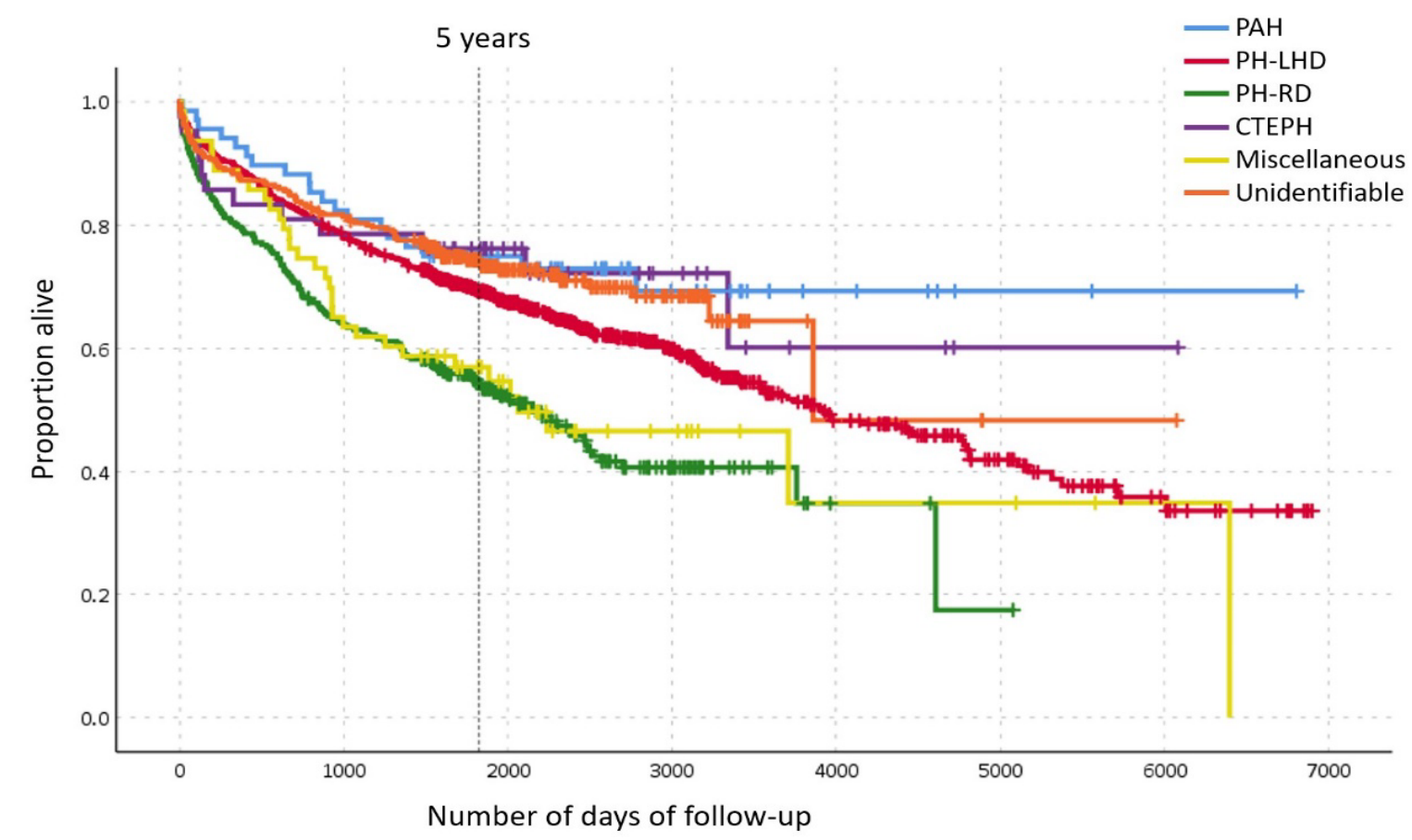

Figure 4. Kaplan-Meier Survival curves depicting the survival of patients according to the clinical classification of $\mathrm{PH}$. PH-RD was associated with the worst prognosis. $\mathrm{PAH}=$ Pulmonary Arterial Hypertension, $\mathrm{PH}-\mathrm{LHD}=$ Pulmonary Hypertension due to left heart disease, $\mathrm{PH}-\mathrm{RD}=$ Pulmonary Hypertension due to respiratory disease, CTEPH= Chronic Thromboembolic Pulmonary Hypertension 
medRxiv preprint doi: https://doi.org/10.1101/2020.09.19.20197988; this version posted September 22, 2020. The copyright holder for this preprint (which was not certified by peer review) is the author/funder, who has granted medRxiv a license to display the preprint in perpetuity.

It is made available under a CC-BY 4.0 International license .

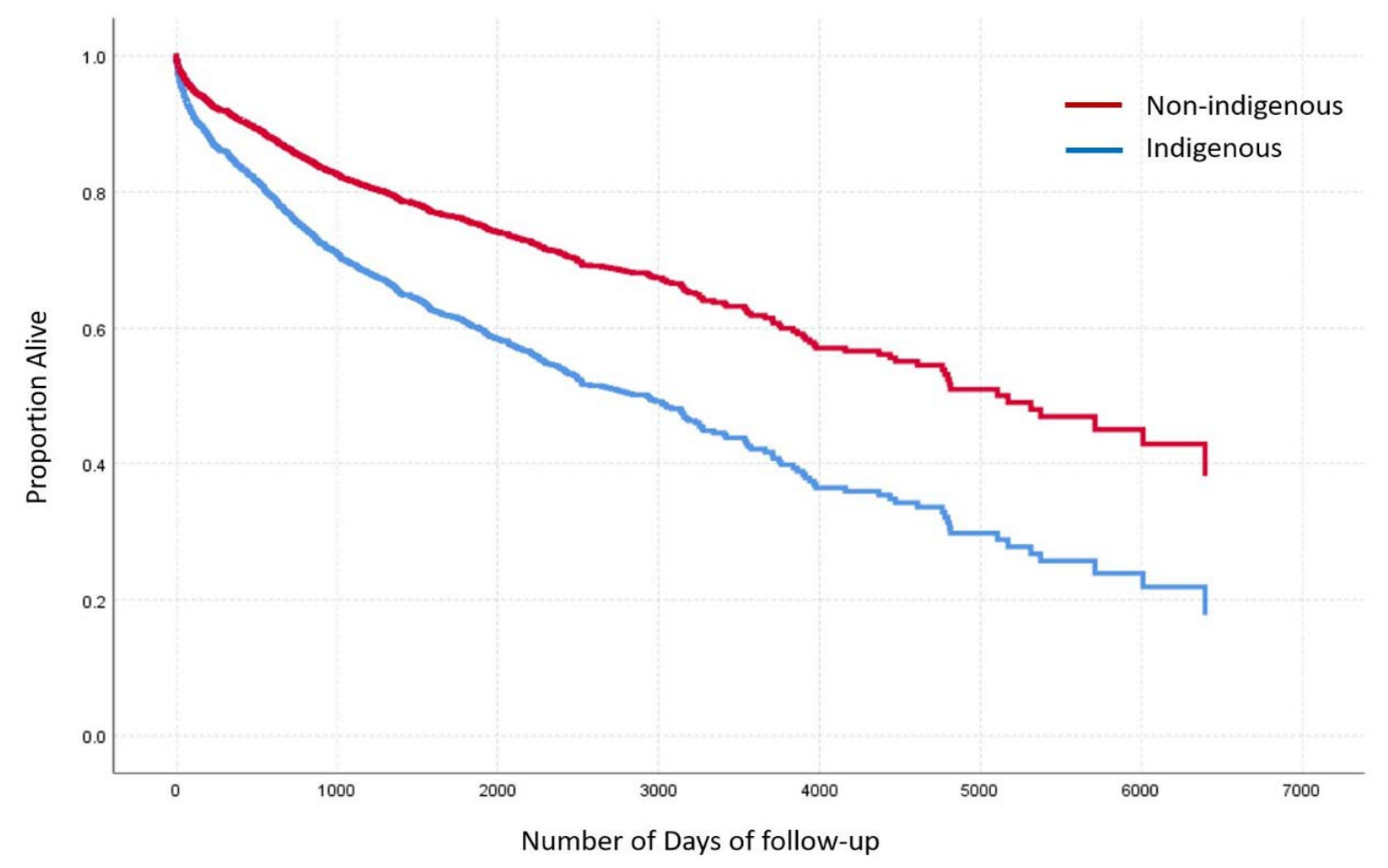

Figure 5. The survival curves of Indigenous and non-Indigenous patients constructed using multivariate Cox regression analysis. Hazard ratio=1.796 (1.496-2.155), $\mathrm{P}=<0.001$. Covariates = age at diagnosis, gender and estimated pulmonary artery systolic pressure (ePASP). 